\title{
A Hydrofracturing-Triggered Earthquake Occurred Three Years after the Stimulation
}

\author{
Stanisław Lasocki ${ }^{1, *(\mathbb{D})}$, Łukasz Rudziński ${ }^{1}{ }^{1}$, Antek K. Tokarski ${ }^{2}$ and Beata Orlecka-Sikora ${ }^{1}(\mathbb{D})$ \\ 1 Institute of Geophysics, Polish Academy of Sciences, Księcia Janusza 64, 01-452 Warszawa, Poland; \\ rudzin@igf.edu.pl (Ł.R.); orlecka@igf.edu.pl (B.O.-S.) \\ 2 Research Centre in Krakow, Institute of Geological Sciences, Polish Academy of Sciences, Senacka 1, \\ 31-002 Krakow, Poland; ndtokars@cyf-kr.edu.pl \\ * Correspondence: lasocki@igf.edu.pl
}

check for updates

Citation: Lasocki, S.; Rudziński, Ł.; Tokarski, A.K.; Orlecka-Sikora, B. A Hydrofracturing-Triggered Earthquake Occurred Three Years after the Stimulation. Energies 2022, 15, 336. https://doi.org/10.3390/ en15010336

Academic Editor: Yangkang Chen

Received: 30 November 2021

Accepted: 30 December 2021

Published: 4 January 2022

Publisher's Note: MDPI stays neutral with regard to jurisdictional claims in published maps and institutional affiliations.

Copyright: (C) 2022 by the authors. Licensee MDPI, Basel, Switzerland. This article is an open access article distributed under the terms and conditions of the Creative Commons Attribution (CC BY) license (https:// creativecommons.org/licenses/by/ $4.0 /)$.

\begin{abstract}
Hydrofracturing, used for shale gas exploitation, may induce felt, even damaging earthquakes. On 15 June 2019, an $\mathrm{M}_{\mathrm{W}} 2.8$ earthquake occurred, spatially correlated with the location of earlier exploratory hydrofracturing operations for shale gas in Wysin in Poland. However, this earthquake was atypical. Hydrofracturing-triggered seismicity mainly occurs during stimulation; occasionally, it continues a few months after completion of the stimulation. In Wysin, there were only two weaker events during two-month hydrofracturing and then 35 months of seismic silence until the mentioned earthquake occurred. The Wysin site is in Gdańsk Pomerania broader region, located on the very weakly seismically active Precambrian Platform. The historical documents, covering 1000 years, report no natural earthquakes in Gdańsk Pomerania. We conclude, therefore, that despite the never observed before that long lag time after stimulation, the $M_{w} 2.8$ earthquake was triggered by hydrofracturing. It is possible that its unusually late occurrence in relation to the time of its triggering technological activity was caused by changes in stresses due to time-dependent deformation of reservoir shales. The Wysin earthquake determines a new time horizon for the effect of HF on the stress state, which can lead to triggering earthquakes. Time-dependent deformation and its induced stress changes should be considered in shall gas reservoir exploitation plans.
\end{abstract}

Keywords: hydrofracturing; injection-induced seismicity; shale gas

\section{Introduction}

Hydraulic fracturing (HF) is a high-pressure liquid injection technique to increase rocks' matrix permeability. It is routinely used to exploit unconventional hydrocarbon reservoirs, often located in shale formations (e.g., [1]).

Like any technics used for go-resources exploitation, HF can also have adverse effects. Among them is anthropogenic seismicity [2]. It is well known that shale gas extraction based on HF may induce or trigger seismic events. A comprehensive summary of cases from Canada, the United Kingdom, the United States, and China can be found in $[3,4]$. However, as the authors of the cited publications indicate, only a very small fraction of HF wells are associated with induced seismic events. Nevertheless, the events like, e.g., the two M5+ $(2018,2019)$ earthquakes in Sichuan province, China [5,6], and the M4+ earthquakes in Canada and the US ([3], Table 2), exemplify a possible destructive potential of the HF-induced seismicity and evoke understandable public concern.

Typically, the HF-induced seismic events are located closed to the inducing HF operations, within some 1-2 km of HF operations [3,7]. However, much larger distances between the location of seismic events and their triggering operations are also reported. Two of the four largest HF-induced seismic events that occurred in the Sichuan Basin in China in 2017 were located 2.8 and $3.1 \mathrm{~km}$ from the well pad, respectively [6]. Chapman [8] indicated eight earthquakes from the Peace River Region of British Columbia in Canada that were 
distinctly associated with hydrofracturing, and whose triggering HF operations were more than $5 \mathrm{~km}$ from their epicenters.

The vast majority of HF-induced seismic events occur during stimulation, and this seismic activity decays quickly, within a few days after the well shut-in [3,4]. Some cases of protracted activity are also known. However, this activity did not last longer than a few months after fracturing ended, e.g., over a month in two out of five cases in Ohio investigated in [9], or three months as reported from the Western Canada Sedimentary Basin [10].

In this paper, we present and discuss the case of the $\mathrm{M}_{\mathrm{w}} 2.8$ earthquake in Wysin, Poland, which was most likely triggered by HF exploration operations. However, it occurred 35 months after the operation shut-in. Such a long lag time between HF and an HF-triggered earthquake has not been reported so far.

\section{Materials and Methods}

In Poland, the interest in gas in shale formations began in 2000. The US Energy Information Administration assessed technically recoverable resources at $4.13 \times 10^{3}$ billion cubic metres $(\mathrm{Bcm})$ [11]. The Polish Geological Institute estimates of 340-753 Bcm [12] and USGS of $38 \mathrm{Bcm}$ were not that optimistic; nevertheless, Poland's shale gas potential seemed to be a great opportunity to gain new energy resources.

A total of 72 exploratory drillings for shale gas in Poland were performed. Although they found gas, the generated outflows, which determined the profitability of production, were at a significantly lower level than expected. It was concluded that gas recovery from Polish shale formation was economically not viable. The last trial was undertaken by Polish Oil and Gas on the Wysin site in Gdańsk Pomerania between 2014 and 2016.

The action plan in the Wysin site included drilling a vertical well to reach the target shale strata and two horizontal boreholes for hydraulic fracturing. The vertical well, located at $54.0942 \mathrm{~N}, 18.3054 \mathrm{E}$ (wellhead), was drilled to a depth of about $4 \mathrm{~km}$ below ground level. It was completed in 2013. The horizontal boreholes, beginning from the same drilling pad, extended some $1.7 \mathrm{~km}$ each in two opposite, west-south-west and east-north-east directions. The horizontal boreholes were drilled in June-July 2015 and September-October 2015, respectively, and fracked in June 2016 and July 2016, respectively ([13] and the references therein).

As with all previous trials in other sites, the gas output from the Wysin site was not satisfactory. The shale gas operations in Wysin, likewise elsewhere in Poland, were suspended in Autumn 2016.

The Polish shale gas boom coincided with huge discussions in Europe regarding HF operations' safety for unconventional hydrocarbon exploitation purposes following the HFinduced M2.3 felt earthquake near Blackpool, UK, in 2011 [14]. To frame these discussions in hard facts, The European Commission undertook actions fostering research into the HF-induced environmental hazards. They included, among others, the European H2020 call LCE-16-2014: “Understanding, preventing, and mitigating the potential environmental impacts and risks of Shale Gas Exploration and Exploitation". The call led to the financing of four research projects in 2015-2018. Among these four was the SHEER project (SHale gas Exploration and Exploitation induced Risks [15]), carried out by an international consortium of eight research institutions from seven countries [13]. SHEER aimed at developing best practices for assessing and mitigating the environmental footprint of shale gas exploration and exploitation. As the only one from the mentioned four projects, SHEER included on-site monitoring of seismicity, water contamination, and air pollution before, during, and after actual HF operations for shale gas exploitation. The site monitored in the framework of the SHEER project was Wysin.

The SHEER's seismic monitoring was carried out from 2015 to 2017. The surface setup consisted of a close-to-equilateral triangle of three small-scale arrays located at an average distance from the Wysin rig of $2.9 \mathrm{~km}$. The arrays comprised eight to nine short-period stations and one broadband station. Furthermore, three broadband stations at about $5 \mathrm{~km}$ 
from the rig supported the arrays' observations. In addition to the surface network, we placed three seismometers in shallow $(50-60 \mathrm{~m})$ boreholes at a horizontal distance of about $500 \mathrm{~m}$ from the track of the horizontal boreholes for fracking. The surface monitoring setup was fully operational from July to August 2015, and the borehole seismometers were from February 2016. The network and the applied processing technique could record HF-triggered seismic events from $\mathrm{M}_{\mathrm{w}} 0.5[16,17]$.

In March 2016, the seismic monitoring network was supplemented by two pairs of broadband stations. The stations of pairs were located symmetrically to the injection well, and the pairs were nearly perpendicular to one another. The pairs stations' spacing was $15 \mathrm{~km}$ and $20 \mathrm{~km}$, respectively.

In the presented setup, we carried out the seismic monitoring until January 2017, covering a period well before, during, and after the HF operations. The setup was then reduced to 16 short-period three broadband and three borehole stations, but we continued the monitoring until May 2017 to trace any longer-lasting seismic effects.

Throughout the whole monitoring period, except for the micro-seismicity resulting from pumping, only two weak events $\left(\mathrm{M}_{\mathrm{W}} 1.0\right.$ and $\left.\mathrm{M}_{\mathrm{w}} 0.5\right)$ were detected that might have been triggered by HF operations, as they occurred days after fracturing stages in a vicinity of the injection well. However, they were shallow, less than $150 \mathrm{~m}$ depth [18].

After 35 no-seismicity months since the HF operations' termination, on 15 June 2019, an $\mathrm{M}_{\mathrm{w}} 2.8$ earthquake occurred nearby Wysin. The time scale of the hydrofracturing works, the SHEER's seismic monitoring with the recorded occurrences of the two seismic events, and the occurrence of the earthquake from 15 June 2019 is shown schematically in Figure 1.

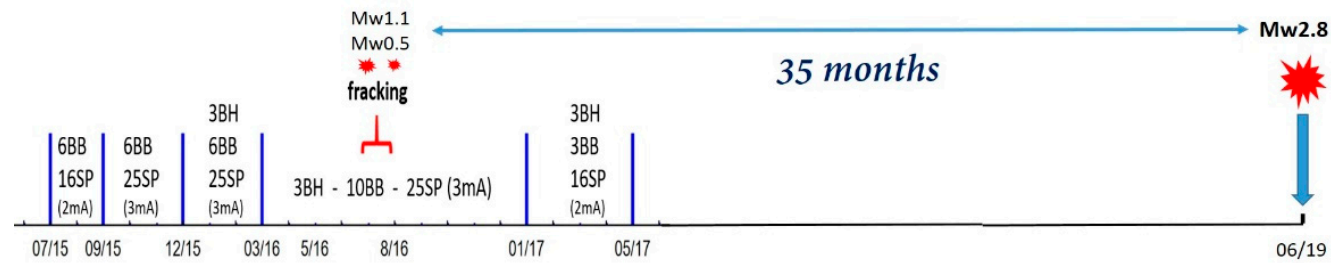

Figure 1. Schematic time scale of seismic monitoring around the Wysin site in the framework of the SHEER project, hydrofracturing works in horizontal boreholes, the occurrence of two seismic events recorded by the SHEER monitoring network, and the occurrence of the earthquake discussed in the present paper.

The seismic monitoring setup around the site, which had been used by the SHEER project, was decommissioned 25 months before the occurrence of the discussed event. At its time of occurrence, the closest local seismic network was about $80 \mathrm{~km}$ north of the Wysin site. The network purpose was seismic monitoring in the framework of a commercial project carried out by the Institute of Geophysics Polish Academy of Sciences. The customer restricted information on the location of the seismic stations and the recorded seismograms exclusively for the use of the service provider.

At the time of the discussed event, 15 June 2019, the mentioned network consisted of nine short-period and one very broadband seismometers, and had some $25 \mathrm{~km}$ W-E by $15 \mathrm{~km}$ N-S dimensions. The discussed event was recorded by all 10 stations. Due to the above-mentioned restrictions, the records of this event are not publicly available.

We located the source using LocSAT software [19,20] with a local velocity model [21]. The seismic moment was estimated based on spectral level approximation [22,23] using both $\mathrm{P}$ and $\mathrm{S}$ waves trains. The final moment was determined using an assumption of a low-frequency level of the far-field displacement [24].

After the event, in July and August 2019, we installed four broadband seismic stations in the Wysin region to monitor further seismicity. The monitoring was continued until the end of June 2020. We inspected the waveforms in a standard way and using the PyMPA Template Phase Matching Algorithm, a highly efficient technique to detect microseismicity $[25,26]$. 
The Wysin site is in the Gdańsk Pomerania broader region, located on the very weakly seismically active Precambrian Platform. There is no record of an earthquake occurring there in all available historical documents that go back 1000 years $[27,28]$ (see Figures 2 and 3).

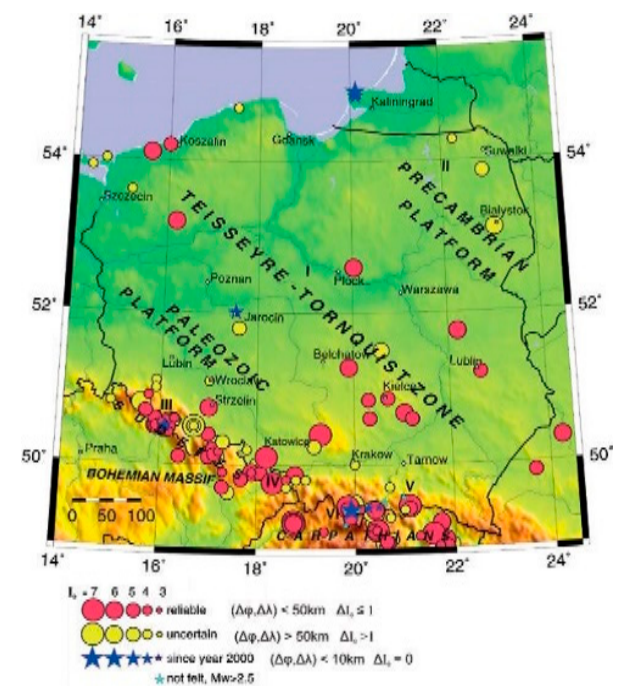

Figure 2. Seismicity in Poland since the XVI century ([28], Figure 3.1 Reprinted by permission from Springer Nature and Copyright Clearance Center: Springer International Publishing: Cham, Switzerland, GeoPlanet: Earth and Planetary Sciences-Studies of Historical Earthquakes in Southern Poland by Guterch, B., Kozák, J., Eds., Chapter 3: Seismicity in Poland: Updated Seismic Catalog by Guterch, B. (C) Springer International Publishing Switzerland (2015)).

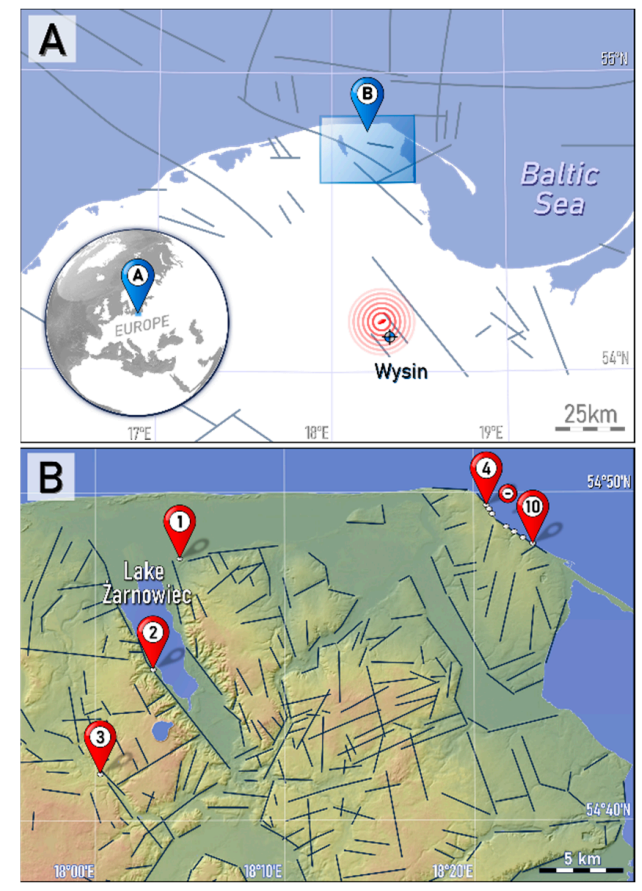

Figure 3. (A) The locations of the Wysin hydrofracturing site and epicenter of the $\mathrm{M}_{\mathrm{w}} 2.8$ earthquake from 15 June 2019 in the Gdańsk Pomerania region. Lines indicate the locations of faults. Circular inset A shows the region location in Europe. Inset B shows the location and area of subfigure (B). (B) The part of the Gdańsk Pomerania region where the studies of gravels bearing fractured clasts were conducted. The locations of the studied exposures are indicated by pins 1-10. Lines indicate the location of lineaments. 
In this connection, we based an extension of the paleoseismic record in this area on the analysis of fractured clasts in Quaternary gravels, as clast-fracturing in gravels can result from seismic faulting [29] and fracturing of crystalline rocks clasts is restricted to M5+ [30].

We carried on the clasts studies in 10 exposures of Pleistocene strata, all located at the NNW to NW/SSE to SE trending lineaments (Figure 3B), in a northern part of Gdańsk Pomerania (Figure 3A). However, the stress pattern of Gdańsk Pomerania is consistent [31]; therefore, our conclusions regarding quaternary seismicity in the northern part of Pomerania remain valid for the whole area.

\section{Results}

\subsection{The $M_{w} 2.8$ Event}

The event's origin time was 15 June 2019 22:28:31:6 UTC, and the epicentral coordinates were $54.1395 \mathrm{~N}, 18.2849 \mathrm{E}$, with the error ellipse of the major axis having a length of $4.1 \mathrm{~km}$ and minor axis length of $1.55 \mathrm{~km}$. Because the source was located outside the seismic network, the hypocentral depth could not be resolved well and was fixed to $5 \mathrm{~km}$. The epicenter was $4.8 \mathrm{~km}$ north of the end of one from two fracked horizontal boreholes at Wysin (Figure 4). The event's magnitude was evaluated to be $\mathrm{M}_{\mathrm{W}} 2.8$.

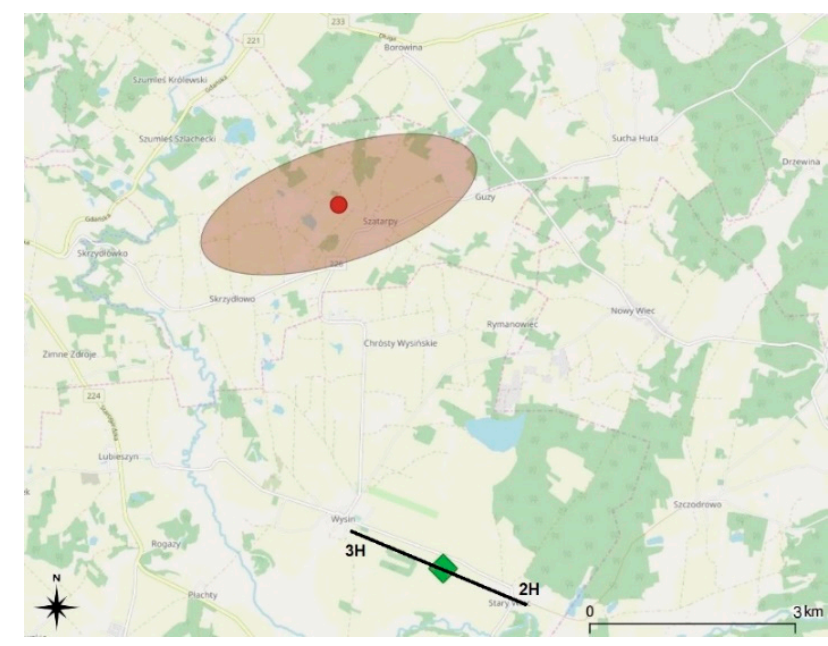

Figure 4. Location of the epicenter (red circle), errors ellipse, Wysin site (green diamond), and approximate extension of the horizontal boreholes.

We detected no other local seismic events from the data from the immediately reinstalled four broadband seismic stations in the Wysin region.

\subsection{Neotectonic Seismic Faulting in Gdańsk Pomerania}

In all 10 exposures, in which we carried on clast studies (Figure 3B), the clasts of crystalline and sedimentary rocks were fractured (Figure 5). At exposure 2, the architecture of clast-cutting fractures was well-organized (Figure 6A), indicating that the fractures were tectonic features [29,32]. Moreover, strikes of the clast-cutting fractures were parallel to those of numerous lineaments (Figure 6B) and faults (Figure 6C) in the study area. In addition, the architecture of the fractures at this exposure was compatible with the current orientation of the far-field tectonic stresses (SHmax NNW-SSE) calculated on borehole break-outs for the Gdańsk Pomerania [31]. 

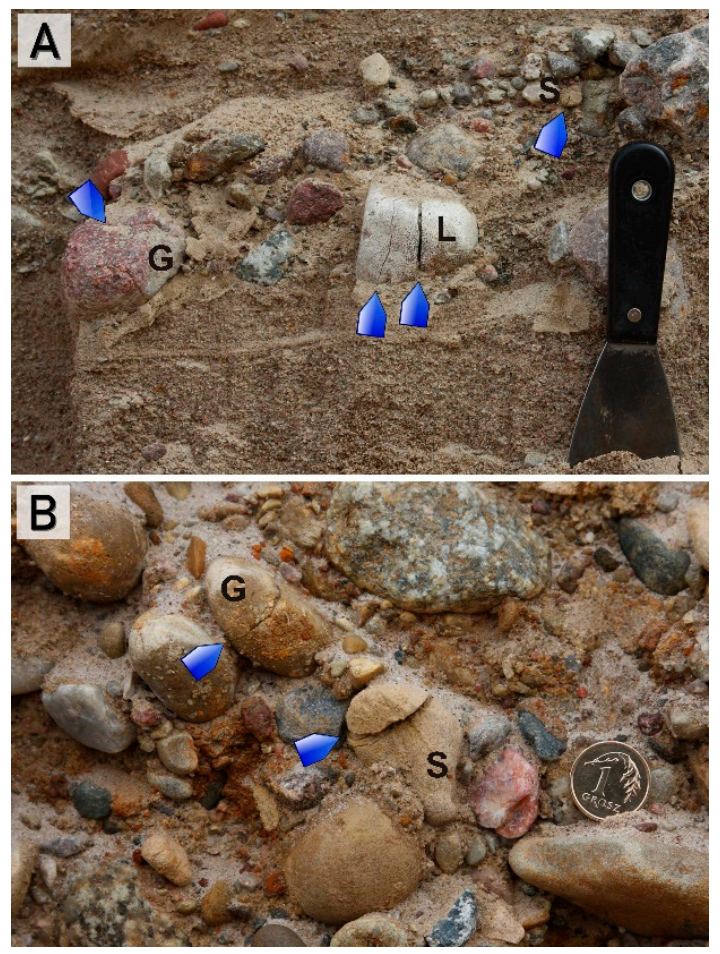

Figure 5. Examples of fractured clasts: (A) from exposure 1, (B) from exposure 3; G-granite; L-limestone; S-sandstone.

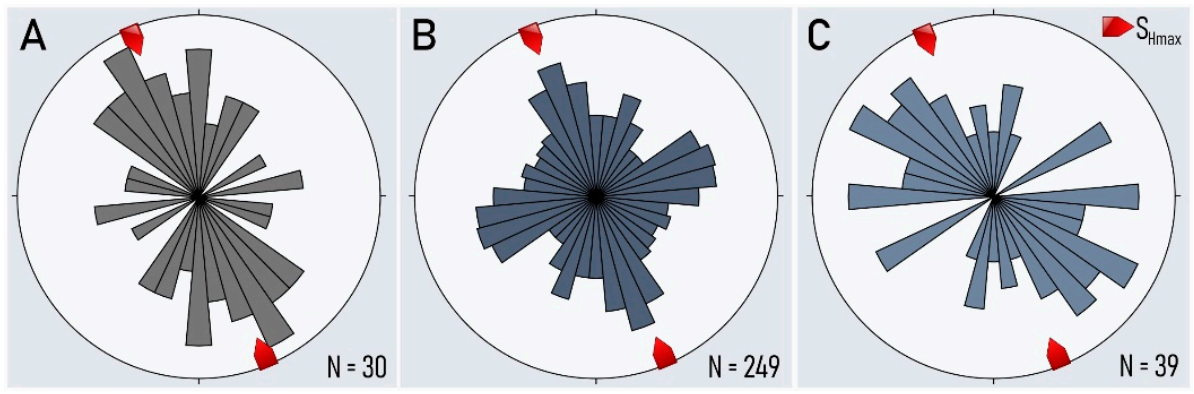

Figure 6. Rose diagram showing (A) the strike of clast cutting fractures at the exposure 2, (B) the orientation of lineaments, and $(\mathbf{C})$ the orientation of fault traces on the Gdańsk Pomerania area.

As mentioned, all exposures of gravels bearing fractured clasts were located at lineaments parallel to numerous mapped faults, suggesting that the lineaments followed un-mapped faults hitherto. Overall, we concluded that clast-fracturing in Pleistocene gravels within the Gdańsk Pomerania resulted from M5+ earthquakes on the NNW to NW/SSE to SE trending faults in the quaternary.

\section{Discussion}

The clast-fracturing analysis shows that there are pre-stressed faults in the Gdańsk Pomerania region, specifically in the Wysin region-a necessary condition for either natural or triggered earthquake occurrence.

The absence of any mention in historical documents from the last millennium of earthquake occurrence in the broader region of Gdańsk Pomerania indicates the natural earthquakes return periods of thousands of years. The event from 15 June 2019 occurred only about $5 \mathrm{~km}$ from the location of the previous HF operations, and only about three years after these operations. The extremely low probability of such a random space-time coincidence argues against the natural origin of the Wysin event. 
Except for the HF operations in the Wysin site, there had not been any technological activity capable of triggering earthquakes in that rural area. Therefore, if the investigated event of 15 June 2019 was triggered, it could not be triggered by any other, except technological, activities in Wysin.

According to the error ellipse dimensions (Figure 4), the distance between the horizontal borehole and the event's epicenter could be even as small as $3.7 \mathrm{~km}$. Such a distance is capable of providing coupling that results in a triggered earthquake. This distance is comparable, e.g., to the one, approximately $2 \mathrm{~km}$, often seen for larger HF-triggered seismic events [3]; the one, greater than $3 \mathrm{~km}$, provided in [6]; and the one mentioned for eight earthquakes from the Montney Trend of northeast British Columbia, Canada, of more than $5 \mathrm{~km}$ [8]. The Ohio Department of Natural Resources regulations (cited in [33]) require seismicity monitoring when an HF well is located within $4.8 \mathrm{~km}$ from a fault. Such an approach suggests that the hazard of earthquake triggering at distances to some $5 \mathrm{~km}$ is not considered negligible. A factor favoring triggering at the extended distance from the Wysin HF operations could be the location of injections above the crystalline basement [34].

However, the 35-month time elapsed between the HF and the event's occurrence on 15 June 2019 makes this event atypical. Moreover, these were seismically silent months, whereas most HF-induced seismicity occurs during the technological operations and continues uninterrupted until it expires, typically a few days after completion of the operations.

Nevertheless, there have been cases when the HF-triggered activity lasted longer [4]. The most delayed event in the study of Ghofrani and Atkinson [10] occurred 92 days after HF. The authors argue that there is no sharp time limit between HF operations and triggered seismic events. The seismic activity in the Kiskatinaw area of British Columbia, Canada, continued at a reduced rate throughout the whole COVID-19 pandemic-enforced shut down of activities from April to August 2020 [35]. Atkinson et al. [3] mention that hydrofracturing-induced seismic events may occur with a time lag of up to years.

The observed unusually long delay between the HF operations in the Wysin site and the discussed earthquake may have been caused by changes in stresses due to timedependent deformation of reservoir shales. The time-dependent response was studied in the laboratory [36-39] and simulation experiments [40]. It has been shown that such a response takes the form of either a recoverable viscoelastic [37,39] or permanent viscoplastic deformation [36,38], and that the amount of time-dependent deformation depends on the shale rock types. In some cases, the impact of the time-dependent deformation on stress changes may be significant and extend over years.

Jarosiński [31] suggested that recent far-field tectonic forces controlled the stress field in Poland. Regarding the Gdańsk-Pomerania region, a gentle, systematic rotation of SHmax, currently NNW-SSE, towards the NW-SE trend of the Teisseyre-Tornquist Zone, and a stable strike-slip stress regime was reported. It is then possible that the superposition of the neotectonic stresses and the stresses caused by the time-dependent deformation were responsible for the Wysin earthquake.

\section{Conclusions}

In light of the gathered facts, we conclude that earlier hydrofracturing operations triggered the Wysin earthquake. It is possible that the occurrence of this event so long after the HF operations in the Wysin site was caused by changes in stresses due to timedependent deformation of reservoir shales. This so-far not observed lag time between the earthquake and its trigger determines a new time horizon for the effect of HF on stress state, which can lead to triggering earthquakes and should stimulate a revision of the current views on triggering earthquakes with hydrofracturing. Time-dependent deformation and its induced stress changes should be considered in shall gas exploitation plans.

Author Contributions: Conceptualization, S.L. and Ł.R.; methodology, S.L., Ł.R. and A.K.T.; formal analysis, Ł.R. and A.K.T.; investigation, S.L., Ł.R., B.O.-S. and A.K.T.; data curation, Ł.R. and A.K.T.; writing-original draft preparation, S.L., A.K.T., B.O.-S. and Ł.R.; writing-review and editing, S.L., 
A.K.T., B.O.-S. and Ł.R.; visualization, A.K.T., Ł.R. and S.L. All authors have read and agreed to the published version of the manuscript.

Funding: The publication was created as part of the project co-financed by the Ministry of Education and Science under the agreement No. 2021/WK/09. This research was also partially funded by the National Statutory Activity of the Ministry of Education and Science of Poland No 3841/E-41/S/2021.

Institutional Review Board Statement: Not applicable.

Informed Consent Statement: Not applicable.

Data Availability Statement: The seismic data and all other data acquired in the SHEER project's monitoring campaign from 2015 to 2017, and the seismic data from four stations installed in the Wysin region after the earthquake on 15 June 2016 are openly available via EPISODES Platform in the episode Wysin https:/ / tcs.ah-epos.eu/\#episode:WYSIN at doi:10.25171/InstGeoph_PAS_ISEPOS-2017-012 (accessed on 3 January 2021).

Acknowledgments: The assistance of Leopold Stempowski, Beata Plesiewicz, Jan Wiszniowski, and Piotr Sałek in reviewing waveforms, and Piotr P. Woźniak during fieldwork is highly appreciated. We are thankful to Piotr Strzelecki and Ania Świerczewska for technical help. We also wish to express our gratitude to the Editor and the anonymous Reviewers for their valuable comments, which improved this article.

Conflicts of Interest: The authors declare no conflict of interest. The funders had no role in the design of the study; in the collection, analyses, or interpretation of data; in the writing of the manuscript; or in the decision to publish the results.

\section{References}

1. King, G.E. Hydraulic fracturing 101: What every representative, environmentalist, regulator, reporter, investor, university researcher, neighbor and engineer should know about estimating frac risk and improving frac performance in unconventional gas and oil wells. In Proceedings of the SPE Hydraulic Fracturing Technology Conference, The Woodlands, TX, USA, 6 February 2012. [CrossRef]

2. Lasocki, S.; Orlecka-Sikora, B. Anthropogenic Seismicity Related to Exploitation of Georesources. In Encyclopedia of Solid Earth Geophysics; Gupta, H., Ed.; Encyclopedia of Earth Sciences Series; Springer: Cham, Switzerland, 2020. [CrossRef]

3. Atkinson, G.M.; Eaton, D.W.; Igonin, N. Developments in understanding seismicity triggered by hydraulic fracturing. Nat. Rev. Earth Environ. 2020, 1, 264-277. [CrossRef]

4. Schultz, R.; Skoumal, R.J.; Brudzinski, M.R.; Eaton, D.; Baptie, B.; Ellsworth, W. Hydraulic fracturing-induced seismicity. Rev. Geophys. 2020, 58, e2019RG000695. [CrossRef]

5. Lei, X.; Wang, Z.; Su, J. The December 2018 ML 5.7 and January 2019 ML 5.3 earthquakes in South Sichuan Basin induced by shale gas hydraulic fracturing. Seismol. Res. Lett. 2019, 90, 1099-1110. [CrossRef]

6. Meng, L.; McGarr, A.; Zhou, L.; Zang, Y. An investigation of seismicity induced by hydraulic fracturing in the Sichuan Basin of China based on data from a temporary seismic network. Bull. Seismol. Soc. Am. 2019, 109, 348-357. [CrossRef]

7. Skoumal, R.J.; Barbour, A.J.; Brudzinski, M.R.; Langenkamp, T.; Kaven, J.O. Induced seismicity in the Delaware Basin, Texas. J. Geophys. Res. Solid Earth 2020, 125, e2019JB018558. [CrossRef]

8. Chapman, A.R. Hydraulic fracturing, cumulative development and earthquakes in the Peace River Region of British Columbia, Canada. J. Geosci. Environ. Prot. 2021, 9, 55-82. [CrossRef]

9. Kozłowska, M.; Brudzinski, M.R.; Friberg, P.; Skoumal, R.J.; Baxter, N.D.; Currie, B.S. Maturity of nearby faults influences seismic hazard from hydraulic fracturing. Proc. Natl. Acad. Sci. USA 2018, 115, E1720-E1729. [CrossRef]

10. Ghofrani, H.; Atkinson, G.M. Activation rate of seismicity for hydraulic fracture wells in the Western Canada Sedimentary Basin. Bull. Seismol. Soc. Am. 2020, 110, 2252-2271. [CrossRef]

11. US EIA/ARI. Technically Recoverable Shale Oil and Shale Gas Resources: An Assessment of 137 Shale Formations in 41 Countries Outside the United States (2013); US Energy Information Agency and Advanced Research Institute: Washington, DC, USA, 2013. Available online: http:/ / www.eia.gov/analysis/studies/worldshalegas/pdf/fullreport.pdf (accessed on 29 November 2021).

12. PGI NRI. Assessment of Shale Gas and Shale Oil Resources of the Lower Paleozoic Baltic-Podlasie-Lublin Basin in Poland (2012); Polish Geological Institute-National Research Institute: Warsaw, Poland, 2012. Available online: https://www.pgi.gov.pl/en/ dokumenty-pig-pib-all/aktualnosci-2012/zasoby-gazu/769-raport-en/file.html (accessed on 29 November 2021).

13. Gunning, A.P.; Lasocki, S.; Capuano, P. Assessing environmental footprints induced by geo-energy exploitation: The shale gas case. Acta Geophys. 2019, 67, 279-290. [CrossRef]

14. Clarke, H.; Eisner, L.; Styles, P.; Turner, P. Felt seismicity associated with shale gas hydraulic fracturing: The first documented example in Europe. Geophys. Res. Lett. 2014, 41, 8308-8314. [CrossRef]

15. European Commission. SHale Gas Exploration and Exploitation Induced Risks. Available online: https://cordis.europa.eu/ project/id/640896 (accessed on 30 November 2021). 
16. López-Comino, J.A.; Cesca, S.; Kriegerowski, M.; Heimann, S.; Dahm, T.; Mirek, J.; Lasocki, S. Monitoring performance using synthetic data for induced microseismicity by hydrofracking at the Wysin site (Poland). Geophys. J. Int. 2017, $210,42-55$. [CrossRef]

17. Karamzadeh, N.; Kühn, D.; Kriegerowski, M.; López-Comino, J.A.; Cesca, S.; Dahm, T. Small-aperture array as a tool to monitor fluid injection- and extraction-induced microseismicity: Applications and recommendations. Acta Geophys. 2019, 67, 311-326. [CrossRef]

18. López-Comino, J.A.; Cesca, S.; Jarosławski, J.; Montcoudiol, N.; Heimann, S.; Dahm, T.; Lasocki, S.; Gunning, A.; Capuano, P.; Ellsworth, W.L. Induced seismicity response of hydraulic fracturing: Results of a multidisciplinary monitoring at the Wysin site, Poland. Sci. Rep. 2018, 8, 8653. [CrossRef] [PubMed]

19. Bratt, S.R.; Bache, T.C. Locating events with a sparse network of regional arrays. Bull. Seismol. Soc. Am. 1988, 78, 780-798.

20. Bratt, S.R.; Nagy, W. The LocSAT Program; Science Applications International Corporation: San Diego, CA, USA, 1991.

21. Majdański, M. The structure of the crust in TESZ area by kriging interpolation. Acta Geophys. 2012, 60, 59-75. [CrossRef]

22. Andrews, D.J. Objective determination of source parameters and similarity of earthquakes of different size. In Earthquake Source Mechanics; Das, S., Boatwright, J., Scholz, C.H., Eds.; Geophysical Monograph Series; American Geophysical Union: Washington, DC, USA, 1986; Volume 37.

23. Snoke, J.A. Stable determination of (Brune) stress drops. Bull. Seismol. Soc. Am. 1987, 77, 530-538.

24. Boore, D.M.; Boatwright, J. Average body-wave radiation coefficients. Bull. Seismol. Soc. Am. 1984, 74, 1615-1621. [CrossRef]

25. Vuan, A.; Sugan, M.; Chiaraluce, L.; Di Stefano, R. Loading rate variations along a midcrustal shear zone preceding the Mw6.0 earthquake of 24 August 2016 in Central Italy. Geophys. Res. Lett. 2017, 44, 12170-12180. [CrossRef]

26. Vuan, A.; Sugan, M.; Amati, G.; Kato, A. Improving the detection of low-magnitude seismicity preceding the Mw 6.3 L'Aquila earthquake: Development of a scalable code based on the cross correlation of template earthquakes. Bull. Seismol. Soc. Am. 2018, 108, 471-480. [CrossRef]

27. Pagaczewski, J. Catalogue of earthquakes in Poland in 1000-1970 years. Publ. Inst. Geophys. Pol. Acad. Sci. 1972, 51, 3-36.

28. Guterch, B. Chapter 3: Seismicity in Poland: Updated Seismic Catalog. In Studies of Historical Earthquakes in Southern Poland; Guterch, B., Kozák, J., Eds.; GeoPlanet: Earth and Planetary Sciences, Springer International Publishing: Cham, Switzerland, 2015. [CrossRef]

29. Kübler, S.; Friedrich, A.; Gold, R.; Strecker, M. Historical coseismic surface deformation of fluvial gravel deposits, Schafberg fault, Lower Rhine Graben, Germany. Int. J. Earth Sci. 2018, 107, 571-585. [CrossRef]

30. Tokarski, A.K.; Świerczewska, A.; Lasocki, S.; Cuong, N.Q.; Strzelecki, P.J.; Olszak, J.; Kukulak, J.; Alexanderson, H.; Zasadni, J.; Krapiec, M. Active faulting and seismic hazard in the Outer Western Carpathians (Polish Galicia): Evidence from fractured Quaternary gravels. J. Struct. Geol. 2020, 141, 104210. [CrossRef]

31. Jarosiński, M. Recent tectonic stress field investigations in Poland: A state of the art. Geol. Q. 2006, 50, 303-321.

32. Phan, D.P.; Tokarski, A.K.; Świerczewska, A.; Strzelecki, P.J.; Waliczek, M.; Krapiec, M.; Cuong, N.Q. Neotectonic (Miocene to recent) vertical movements in the Lao Cai Basin (Red River Fault Zone, Vietnam): An approach to seismic hazard assessment. J. Asian Earth Sci. 2019, 181, 103885. [CrossRef]

33. Brudzinski, M.R.; Kozłowska, M. Seismicity induced by hydraulic fracturing and wastewater disposal in the Appalachian Basin, USA: A review. Acta Geophys. 2019, 67, 351-364. [CrossRef]

34. Goebel, T.H.W.; Brodsky, E.E. The spatial footprint of injection wells in a global compilation of induced earthquake sequences. Science 2018, 361, 899-904. [CrossRef]

35. Salvage, R.O.; Dettmer, J.; Swinscoe, T.H.A.; MacDougall, K.; Eaton, D.W.; Stacey, M.; Aboud, M.M.; Kang, T.-S.; Kim, S.; Rhie, J.J. Real-time monitoring of seismic activity in the Kiskatinaw area, northeastern British Columbia (NTS 093P, 094A). In Geoscience BC Summary of Activities 2020: Energy and Water, Geoscience BC, Report 2021-02; Geoscience BC: Vancouver, BC, Canada, 2021; pp. 17-30. Available online: https:/ / www.geosciencebc.com/i/pdf/SummaryofActivities2020/EW / Project\%202019-005 _EWSOA2020\%20revised.pdf (accessed on 1 January 2022).

36. Chang, C.; Zoback, M.D. Viscous creep in room-dried unconsolidated Gulf of Mexico shale (I): Experimental results. J. Pet. Sci. Eng. 2009, 69, 239-246. [CrossRef]

37. Sone, H.; Zoback, M.D. Time-dependent deformation of shale gas reservoir rocks and its long-term effect on the in situ state of stress. Int. J. Rock Mech. Min. Sci. 2014, 69, 120-132. [CrossRef]

38. Rassouli, F.S.; Zoback, M.D. Comparison of short-term and long-term creep experiments in shales and carbonates from unconventional gas reservoirs. Rock Mech. Rock Eng. 2018, 51, 1995-2014. [CrossRef]

39. Bao, T.; Burghardt, J.; Gupta, V.; Edelman, E.; McPherson, B.; White, M. Experimental workflow to estimate model parameters for evaluating long term viscoelastic response of $\mathrm{CO}_{2}$ storage caprocks. Int. J. Rock Mech. Min. Sci. 2021, 146, 104796. [CrossRef]

40. Bao, T.; Burghardt, J.; Gupta, V.; White, M. Impact of time-dependent deformation on geomechanical risk for geologic carbon storage. Int. J. Rock Mech. Min. Sci. 2021, 148, 104940. [CrossRef] 